\title{
Marx's Labor Theory of Value. Misleading or Truth?
}

\author{
Gennady Bilych \\ Dept. of Management, UPEC Corporation, Belgorod \\ 20 Popova str., 308000, Belgorod, Russia \\ Tel: 7-472-220-2033Ｅ-mail: genatdht@yandex.ru
}

$\begin{array}{lc}\text { Received: February 15, } 2013 & \text { Accepted: March 4, } 2013 \\ \text { doi:10.5296/ber.v3i1.3259 } & \text { URL: http://dx.doi.org/10.5296/ber.v3i1.3259 }\end{array}$

\begin{abstract}
As once noted by Hicks, an economist's suggestions and recommendations depend on his or her social values and ideological beliefs. But this is not how it should be. Economic science should be the same for liberals, socialists, nationalists, Christians and pagans. I believe that a person's economic viewpoints and ideological beliefs are, to a large extent, defined by their attitude towards profit. Marxists believe that profit is the unpaid labour of an employee. For liberals profit is the rightful reward of such a specific factor of production as "entrepreneurial talent" and serves as compensation for efficient use of resources. Followers of Keynes and others in favour of state regulation assume an intermediate or middle position between Marxists and liberals. They believe that profit does not always end up in the most deserving hands and so under certain circumstances government officials may restrict the freedom of entrepreneurs and in doing so promote a more equitable distribution of profit. The opinions of economists and their recommendations will continue to differ until there is a definite answer to the question - What is profit? This essay is an attempt to answer this question and I hope that it will help to iron out contradictions between the supporters of different ideologies and political beliefs.
\end{abstract}

Keywords: Marx`s Labor Theory of Value, Profit, Capital

\section{Shortcomings of Marx's Theory and Other Existing Theories of Value}

I have no doubt that Marx's labour theory of value was the logical continuation of the achievements of Smith and Ricardo. Marx was their reliable and diligent student, although he denied this in every way. He was, of course, educated in the difficult political and economic conditions of the $19^{\text {th }}$ Century and therefore he developed an uncompromising and aggressive character. Naturally, both Smith and Ricardo had their suspicions concerning the possibility of disputes about the moral value of the nature of entrepreneurial profit. Their work therefore 
has many loopholes which demonstrate this concern. Smith especially emphasises that only in a primitive society is the price of a product defined by the amount of labour time required to produce the item. If labour is the only means of production then the price is proportionate to the amount of labour expended. If capital is also involved in the production process, the price of the product will be equal to the sum of the value of labour and capital. However, an approach such as this does not change anything and the issue of the origin of profit remains. Ricardo rightly saw capital as labour expended in the past. He took production costs to be salaries and profit, therefore Stigler (1946) called his theory of value 93\% of the labour theory of value. Ricardo was well aware of the dangerous conclusions concealed within the labour theory of value. This is why he hastily and unconditionally agreed with Malthus who argued that the exchange values of goods are not proportionate to the labour hired for their production. But all these words do not cancel out the inevitable conclusion: profit is part of the cost of a product. Further conclusions depend entirely on a person's ideological and political beliefs. Some people may consider profit to be the reward given by an entrepreneur or owner of production for efficient organisation of the production process; others may consider profit to be the reward for avoiding immediate consumption and a fair prize for accumulating capital. There is however, a third legitimate opinion: profit is lucre unfairly witheld either from the workers or from the consumers or from both (Mises, 2008). This final statement is not so easy to dismiss, even today it has many supporters. $7 \%-10 \%$ of the total cost of products sold or even more - is this not too high a reward for "entrepreneurial talent"? $90 \%$ of the cost of products sold or less - is this not too little for hard and exhausting labour? What can liberals say in response to this? Firstly, hired workers do not take part in the production process at gunpoint, they do so voluntarily. The main reason for this step is that their salary as part of a firm is higher than in the case of independent activity. Secondly, the argument that an owner of capital has clear advantages in comparison with a person who does not have capital and therefore capital hires labour (Brown, Falk and Fehr, 2002) and exploits it, raises further doubts. Examples of creating social networks on the Internet and personal computers in garages clearly contradict the fundamentals of Marxist theory. After the first major successes of poor, young enthusiasts, owners of major capital, who were eager to participate in the promising business, came in droves to back the enthusiasts. In this case labour was already being hired by capital. But, on the other hand, this argument is also fairly easy to dispute. Knowledge in the modern world has begun to be seen by many people as a special type of capital. Furthermore, in order to receive a good education you have to spend a fair amount of money. A dispute between a Marxist and a liberal may go on indefinitely and it will most likely end without a result. They will both walk away with their heads held high and with the firm conviction that they are in the right. Neither of them has a trump card and therefore Marx's labour theory of value has now been on the periphery of economic thought for more than 100 years and there has never been more than a handful of remarkable defenders of liberalist ideas. Between Marxists and liberals there has grown a large and indestructible army of economists who vote for freedom with one hand and with the other continue to actively regulate and control the economy arguing that there is no other way to be in this imperfect world. This is understandable. If neither of the sides was able to win in battle then the most logical step for the majority would be to maintain neutrality. 
An additional point to emphasize is the special role played by the Austrian school of economics. In the late $19^{\text {th }}$ century and throughout the entire $20^{\text {th }}$ century, representatives of this school were the most consistent critics of the theory of exploitation and they were ardent defenders of liberal ideas. They argued that the value of consumer products and capital goods is determined not by production costs, but by the demand from buyers. Therefore, the price is dependent upon the marginal utility gained by individuals from the consumption of a certain product. This approach helped to calm the situation and slightly cool down the heads of those so vehemently opposed to exploitation. Everybody receives everything in accordance with the principle of marginal utility. Exploitation was forced into a dark corner away from prying eyes. Thanks to the Austrian school, fierce battles among economists turned into peaceful discussions. The most valued ideas of the Austrian economists were successfully incorporated into the main flow of economic thought. However, as is usually the case under these circumstances, many distinguishing features of the Austrian school disappeared or lost their initial shine. Nowadays, many representatives of this school do not protest so actively against government officials interfering in the economy. Freedom is no longer thought of as the most important condition for a successfully functioning market. Regulating the economy is no longer met with the objections of the past. Marxism evolved in a similar manner. Today Marxists do not demand immediate revolutionary changes, or that the fundamentals of institutes of ownership be reviewed. Naturally, criticism from one party or another is still given from time to time, but the old aggression is no longer there. Nobody has signed an agreement on friendship or cooperation, but the weapon has long since been destroyed. Perhaps there is nothing bad in all of this, but the dispute has, nevertheless, not yet been resolved.

The weakness of liberalist arguments did not enable them to attack the very foundations of Marx's theory of value and therefore their criticism was focused on discussing its individual shortcomings. The most important of these is the concept that Marx introduced of "abstract labour" (Marx, 1979). According to Marx, "abstract labour" is the productive expenditure of human nerves and muscles. Of course, nerves and muscles are different in each individual, but he believed that human efforts can be reduced to a certain average level. This level will be a unit of abstract labour. Of course, such a dubious notion as this could not exist without a small uprising. Labour cannot be reduced to simple labour (Bohm-Bawerk, 1948) because the productivity of labour is different in every person. Ricardo also argued that the gain of a month's work of an artist is not the same as the labour of a simple painter and decorator. Over a certain period of time one peasant may harvest 1 ton of grain from his land plot, another -1.5 tons and a third - 900 kilograms. Which labour should be taken as a unit of abstract labour? How should this labour be compared with the labour of a miner or a bank employee? The problems of the labour theory of value did not end there because Marx also introduced the concepts of variable and constant capital. After this step, a standard unit of measurement was required not only for labour, but also for capital. At this point an impossible problem needed to be solved: how to compare metres, tons, litres, pieces, degrees and hectares? A great deal of effort was put into this and it was, of course, not abstract labour but the real labour of many economists. Felipe (2001), Fisher, Solow and Kearl (1977), Klump, McAdam and Willman (2011) and many others all attempted unsuccessfully to solve the so-called aggregation problem. Their efforts were not in vain. The long discussions 
finally ended in a result. Dumenil (1983) and Foley (2000) suggested what I believe to be a simple and elegant solution. Marx encountered the aggregation problem because in his theory money played a secondary role. Of course, labour and capital must be expressed in monetary units. It is the only possible solution; having presented labour and capital in cost units you can compare their values, scale or size. Only in this way can labour and capital be placed into various mathematical equations, in the production function for example. In his work Marx very often expressed variable and constant capital in currency format. It is most likely that he saw this solution, but did not want to use it. Perhaps he thought that with a measure such as this his theory would lose its shine and attraction for the masses of the proletariat and simple workers. Incidentally this solution helps to overcome another problem which Marxist followers have been battling unsuccessfully with for more than a century, much to the ridicule of their ideological opponents.

Marx himself attempted to solve the problem of balancing out the average profit rates in various industries. Despite his promise he was not able to offer anything useful in the end. I will reiterate where the main difficulty lies. There is a firm argument that the relationship between variable and constant capital is different in different industries. This is a very bold assumption and I do not believe that it is an obvious fact. I can vaguely imagine what it was based on. It is not possible to compare labour and capital expressed in quantitative units. Of course, in those times the stable growth of the amount of capital per one worker was an obvious fact that nobody could refute. But where did the certainty come from that the relationship between the amounts of labour and capital are different in different industries? I believe that this question has still not been answered. In actual fact, economists did not have any chance to verify the opinion at the time of the varied organic structure of capital in industries. When measuring capital in standard units it was not possible to verify this. We shall not discuss this matter ad infinitum and for a while we shall agree with Marx. In short, if you believe that profit occurs as the result of incomplete payment of labour time and the organic structure of capital in industries varies then you inevitably arrive at the conclusion that profit rates are different in different industries and these rates change over time. On the other hand, competition must inevitably level out the average profit rates in industries, which is confirmed by empirical observations. There is a clear contradiction between Marx's theory and the observable facts. Therefore Marx's conclusion put several generations of economists on a one-way street. The works of Sraffa (1960), Morishima (1973), Steedman (2003) and Loranger (2004) should be noted. Today, however, this problem does not seem so insoluble considering the suggestion of Dumenil (1983) and Foley (2000). If you look at the relationship between the value of labour and the value of capital in different firms, in different countries and at different times, the results may come as a slight surprise to many. We all know full well that over the course of the last 100 years, for example, the amount of capital per worker has consistently increased. But real salaries have also increased. Real prices for capital equipment and natural resources, taking into account available data, have most likely decreased or remained constant. Therefore you cannot unequivocally argue that the relationship between variable and constant capital has changed over time. What is more, even for people who are far removed from economics, the surprising stability of the share of consumption in a country's GDP is no secret. Keynes (1939) also believed the stability of the 
share of income from labour and income received from property to be a reliably established, yet inexplicable fact. This means that the share of labour in countries does not change over time at all. Of course, findings such as these do not mean that the share of labour and capital in different industries is the same, but they do point to certain ideas. After a great deal of work, Douglas (1949) established that over an entire period of observations in the production industry in the US, New Zealand, Australia and South Africa the share of labour in the end product was close to $2 / 3$ and capital close to $1 / 3$. This is a very interesting result. As Douglas said, this cannot be explained as a mere coincidence. Strangely enough this result did not lead to further active study in this area of economic science. At present there are very few studies on the formation of shares of labour and capital in an end product in different industries and especially in different production companies and firms. We can only hope that this work will be done in the near future. If it is proven that shares of labour and capital in different industries are constant, then this will mean that economists have for a very long time battled with a non-existent problem. The situation probably originated from economists' lack of interest in empirical studies. This is demonstrated by the abundance of examples in economic literature where, when discussing the work of a firm, imaginary, not real, economic indicators of the activity of a certain imaginary enterprise are used. There are absolutely no examples with specific figures of the activity of real firms. This is surprising because economic theory inevitably leads to a conclusion on the stability of the relationship between the values of labour and capital in different industries and at production enterprises. Competition leads to a balancing out of salaries in a whole economy. Every worker should be assigned an amount of capital, the productivity of which will be exactly equal to the productivity of the worker. Any disparity between these values should immediately result in replacing one factor of production with another. This process should lead to a consistent increase in labour and capital. The values of labour and capital should increase at the same rate. This result is obvious.

However, all of this does not solve the problems of Marx's labour theory of value or other theories of value. All theories existing today have one hidden defect - if salaries are only a portion of the value of end products (let us suppose, $93 \%$ of the value, as suggested by Ricardo) then how can all of the products be purchased? The salaries of all the workers are clearly not sufficient in order to buy up all products and services. Of course, the profit of a producer usually goes towards expanding production and obtaining additional capital goods. These funds are used to pay for labour in industries that produce capital goods. However, in these industries there are also profits because a portion of the products must end up as unsold. Consequently, after selling their goods enterprises receive less funds than they had before. In other words they will lose money. Aside from this, there is absolutely no indication of where savings may come from. Salaries are not even sufficient to purchase goods and services and therefore there can be no savings or investments. However, we do see savings, investments and profit in real life, they do exist. How can we solve this paradox? This will be discussed in the following sections of this essay.

\section{Marx's Stationary Economy}

In his work Marx talks about the stationary economy or the economy of simple reproduction. 
It has no additionally produced product and there is no economic growth. He analyses economic conditions that are very rare in real life. Human beings live in conditions of practically constant economic growth. Stationary states are only observed in periods of crisis and decreases in business activity. But even in these periods zero economic growth is extremely rare, we are much more likely to see a fall in production or a slight rise in goods production. Let us consider certain particular features of a stationary economy. It is very clear that in a closed economic system, at every moment in time the following equation must be satisfied:

$$
p Q=w L_{y}
$$

Where $p$ is the cost of a final product, $Q$ is the quantity of products, $w$ is wages and $L$ is the quantity of workers. In this case all of the products will be bought up and all of the wages spent. There are no savings in a stationary state and there can be none. Any attempt to make savings will reduce the value of end products and services. After selling their products companies receive less money than they spent during the production process. They will face losses, which will inevitably lead to a decrease in wages to the value of the savings. There is no profit in these conditions either. All money must go only on consumption; this is the only way to maintain equation (1). It is important to note that competition does not allow production owners and entrepreneurs to spend large amounts on personal consumption. Moreover, under the conditions of simple reproduction, there is no need for the services of entrepreneurs. Every year the same amount of products is produced, the technologies are the same and are known to all. There is no place for innovation in stationary states because it is a synonym of economic growth. Successful innovation always increases labour productivity. Innovation enables you to gain more of an end product from a certain amount of resources than you did before. Obviously the less competition there is, the greater the probability of a worker being exploited. In a centralised economy there is nothing to stop a dictator consuming more than others, there is nothing to prevent increasing the number of government officials or the number of employees in the police force or other security agencies. The lack of rights and freedoms means that some of the workers do not receive full payment for their labour; the marginal product of their labour is not the same as their salary. A portion of the manufactured product is used for the consumption of the growing army of officials and representatives of security forces. Some citizens will have salaries that are lower than the marginal product and other citizens will have salaries that are higher. Exploitation is only possible in a centralised economy and therefore Marx's recommendations indulge in unwarranted optimism. The road to socialism is a road to slavery and poverty.

What is a stationary economy in the competitive conditions of the free market? It is economic crisis of course. Imagine if the economy reached the so-called limit of its production capabilities. All firms are using the most advanced and up-to-date production and management technologies. The productivity of labour is at its maximum, it is not possible to get more of a product from one unit of a resource than we do today. The prices of factors of production are exactly the same as their marginal product. There is no profit and there is nothing to give 
interest on loans obtained previously. Production owners are forced to reduce their workforces in order to pay off debts. Depression and confusion dominate the market. But this is not for long. The desire for profit will force entrepreneurs to bring innovation into the production process, which will enable them to increase production and raise wages. Wages will certainly increase because equation (1) must be fulfilled even in a growing economy. We have skipped ahead slightly, therefore let us return to the stationary state.

For an individual enterprise the production function will be as follows:

$$
p q=w l+r k,
$$

Where $q$ is the quantity of products produced by the enterprise, $l$ is the number of workers at

the enterprise, $r$ is the cost of capital and $k$ is the quantity of capital. The second summand, on the right of the equation, $(r k)$ is the wages of workers occupied in the area of production of capital goods, because it is only in this case that equation (1) will hold true. But in this case where are the profits, investments and savings? They cannot be in the Marx theory because they do not exist under the conditions of simple reproduction. It is like a still painting where time plays no role. In order to explain the nature of profit we have to go to the living world of economic growth.

\section{Speculations of Bohm-Bawerk}

In the late $19^{\text {th }}$ Century and early $20^{\text {th }}$ Century, largely due to the expert and profound criticism of Bohm-Bawerk it was possible to contain the spread of the labour theory of value and cool many hot heads. The strength of Marx's theory lies in its simplicity. It leads to completely defined and unequivocal conclusions and therefore it is very difficult to challenge its ideas. However, I believe that Bohm-Bawerk did an amazing job. The opponent was not defeated, of course, but it did suffer significant losses.

More than 120 years ago in one of his works, Bohm-Bawerk gave an extremely successful example that brings us very close to understanding the nature of profit and interest (Bohm-Bawerk, 1959). It is worth noting that the example concerns a growing economy where there is profit and interest. In Bohm-Bawerk's argument time begins to play a very important role. It is in the case of economic growth where Marx is most vulnerable. Bohm-Bawerk believes that Marx's main error is that he does not differentiate between goods of today and goods that will come in the future, between money today and money in the future. Even if the surplus value is produced exclusively through labour, it will only come after a certain period of time. Where is the exploitation if, at the time, workers receive all of the current value of products that will be produced in the future? Let us discuss this in more detail in order to understand the main idea. Goods that are physically the same, but produced at different times, are not identical because of interest. Let us suppose that for five years a worker manufactures a turbine that is valued at $\$ 5,500$. There is no cause to object to the fact 
that over the five-year period the worker should receive all \$5,500. Marx and all of his followers can breathe a sigh of relief. But when should that payment be made? After five years obviously. The worker cannot receive payment until the turbine is manufactured and sold. However, the worker cannot wait that long, he and his family need money to live on. The worker needs somebody who can give money in advance. A person with money does not necessarily have to be called a capitalist, but we shall not argue with Marx. Luckily or unluckily for the worker, a capitalist arrives on the scene. At the end of the first year the worker is able to request compensation for his labour. The question is what should the payment be for the first year in comparison with the price of the finished turbine? Can it be $\$ 1,100$ because the worker has done one fifth of the work? Bohm-Bawerk's answer is no. The turbine will not be ready for another four whole years. Our worker will receive less than the full value of one fifth of the turbine. Taking the interest rate at the time to be $5 \%$ Bohm-Bawerk concludes that at the end of the first year the worker should receive approximately $\$ 1,000$. We will not try to find fault with the calculations, Bohm-Bawerk's example is actually somewhat more complex. What is important is that the worker receives less than $\$ 1,100$. In his argument against the theory of exploitative interest, Bohm-Bawerk used the interest rate to discount the value of future goods. This argument should not affect the worker because he always asks for payment of interest on the savings he has in the bank, for example. This is what everybody does and no labour theory will prevent this. Aside from the fact that this example raises doubts concerning the validity of Marx's assumptions, it also makes you stop and think. For instance, what connection is there between profit and interest? How can equation (1) hold true if there is profit? Bohm-Bawerk gave a clue stating that the worker is paid the salary at the beginning of the production process. Therefore it is spent on purchasing goods that were produced in the previous period. At a certain moment in time factors of production will certainly receive payment equal to their marginal product. At the same time this payment is also a payment for the product that will be produced in the future. If in the future an innovation is implemented or the production process becomes more efficiently organised, then more of the product may be produced than before. This results in a difference between the value of products produced and costs, which in turn results in profit. In order to not disrupt equation (1), all the profit must be paid immediately to the workers who, for example, are working in the capital goods sector. This is how profit and investments occur in a growing economy. We are very close to understanding the nature of profit, interest, savings and investments. All we need to do is to take one final step.

\section{Solving the Paradox}

Let us imagine an economy where there is no money. It is a simple barter economy. How does profit occur under these circumstances and how can you get it? In order to gain profit you have to produce more of a product than was produced previously or you have to increase production as the result of an exchange. In a society such as this profit can only be materialized in the form of an additionally produced product. In a simple barter economy the words profit and economic growth are synonyms. If you add together all the profits and losses of manufacturers then the result will be exactly the same as the value of economic growth. A monetary economy creates a dense fog of the numerous complicated transfers of 
money and goods involved, inflation appears, as well as real and nominal values of economic indicators, but the equation between profit and growth still holds true. The price for factors of production is determined by the average marginal product. For those producers who use their resources efficiently, the marginal product will be higher than the average value. During the production process they earn profit. Companies where the marginal product is lower than the average incur losses. The sum of profits minus losses will equal the value of additionally produced products or, to put it another way, economic growth. The average market profit is far from a random value. If expressed as a percentage it will be exactly equal to the economic growth expressed as a percentage. Naturally, the interest that is paid for the use of credit facilities is closely linked to the value of average profit. Therefore the interest rate is equal to the value of economic growth. We value today's goods and future goods differently because there will be more of them in the future. We rightly request compensation for credit provided. If we give somebody an amount of money equal to our monthly wage for example then we are entitled in the future to request our future wage. If we return to Bohm-Bawerk's example then it becomes clear that in the case described the interest rate, profit and economic growth are $5 \%$. Consequently, the entrepreneur who advanced the production of the turbine was right to claim compensation of $5 \%$.

The production of a certain firm in stationary state may be represented by equation (2). The expenses (right-hand side of the equation) are equal to income (left-hand side of the equation), there is no profit. In order to gain profit the firm has to obtain more products from the same amount of resources. This can be done by introducing new technology or improving the management of production processes. If this takes place, then after a period of time a company will increase production and receive a profit without altering its expenses:

$$
p q+d(p q)=w l+r k+v_{s}
$$

where $v$ is the company's profit for a $d t$ period of time. Taking (2) into account, we get the following:

$$
d(p q)=v
$$

Growth in the production of a particular company is equal to the profits received thanks to effective and productive use of resources. After summing the output of all enterprises, we get the following for the economy as a whole:

$$
d(p Q)=\sum v_{i}
$$

The last equation confirms that economic growth is equal to total producer profits (further information on this in: Bilych, 2012). What does an entrepreneur do with profit? What steps will he take? He has a number of opportunities to use it. Firstly he could use the profit to expand production and increase capital. In other words he could invest the profit. Secondly, 
the entrepreneur could increase workers' salaries. Thirdly he could make savings. In the first case investments will result in an increase in employment and wages in the sector producing capital goods. Equation (1) will hold true, all of the additional product will be bought up. In the second case the workers may immediately increase their consumption or make savings. Savings will not disrupt equation (1) because these funds will be supplied in the form of credit to other producers or consumers. They will be spent either on investments or on consumption. The amount of investment will be exactly equal to the salaries of workers producing investment goods and resources. Additional consumption will enable other manufacturers to obtain additional profit and make investments. The third case is clearly similar to the second. There are, of course, many other ways of spending profit but the end result will always be the same - investments will be made. This is how it always will be. Any use of profit will inevitably end in investment. This means that manufacturers whose goods are purchased by an entrepreneur will receive extra money. In the end this extra money will turn into investments. An entrepreneur may behave extravagantly or irrationally. Even in these cases equations (1) and (3) will hold true. If the entrepreneur puts their money away in a cupboard or in their garage then this will mean that a certain amount of money has fallen out of circulation. This will result in a decrease in inflation. Goods will go down in price and all of our equations will hold true. After the entrepreneur retrieves his money from the garage and spends it inflation will rise. This points to a clear conclusion: profits always turn into investments, which cause economic growth. Growth may be real, when the production of goods increases, and nominal, when prices increase. The increase in production at a certain enterprise, taking equation (2) into account, may be represented as follows:

$$
\mathrm{d}(p q)=\mathrm{d}(w l)+\mathrm{d}(r k)
$$

In order to come out of a stationary state and earn profit, an entrepreneur has to introduce some kind of innovation at their enterprise or increase labour productivity by the value $\mathrm{d}(\mathrm{wl})$. This is the value that production will increase by also. Profit will be exactly equal to $\mathrm{d}(\mathrm{wl})$. At the next stage all profit will be invested, thus increasing capital. Consequently, the following equation will be true:

$$
\mathrm{d}(w l)=\mathrm{d}(r k)
$$

Therefore at the end of the production cycle we will have:

$$
\mathrm{d}(p q)=\mathrm{d}(w l)+\mathrm{d}(r k)=2 \mathrm{~d}(w l)
$$

An excellent result. End production will be exactly twice as high as the level of investment. This means that in any country the share of consumption will be $2 / 3$ of the GDP, which corresponds perfectly well with existing data that is common knowledge. The Spanish economists Escosura and Roses (2003) estimated the share of labour in various countries at various periods in history and obtained a figure close to $68 \%$. The maximum deviation from this value was no greater than $15 \%$. Reder (1959) concluded that in the private sector of the US economy the share of labour in 1900-1909 was $68.0 \%$ and in $1947-1952$ it was $71.5 \%$. According to Cociuba (2010), the share of capital in the product from 1991-2006 in Poland 
was $37 \%$ and in 2006 in the region of East Germany it was 34\%. Shirinko, Fazzari and Meyer (1999) estimated the share of capital in the US at $25 \%-40 \%$. These results correspond fairly well with our conclusions.

However, we should primarily be interested in the share of labour and capital at the level of individual firms and industries. Our analysis examined the work of an individual production enterprise, therefore we are entitled to hope that the organic structure of capital should be the same in all industries. Figure 1 shows the shares of labour in various industries of the US economy. On one hand the results are complex, but on the other hand they do give a certain hope. We need to carefully deal with the data that we have in our possession today. Which payments are included in payment for labour and which are not? How is wear and tear of capital equipment recorded? What else is included as capital costs? Figure 1 does not include data from the agricultural sector. Economists never take this data into consideration when discussing the shares of factors of production in the end product. This is because in these industries the share of labour of production owners and members of their family is high. It is therefore difficult or almost impossible to place a figure on all of the payments that need to be included in the total sum for the payment of labour. There are similar problems in other sectors. Aside from this there are also many other difficulties that need resolving. Further research is needed in this area, especially in-depth analysis of the shares of labour and capital for individual firms. Only after this will we be able to make final conclusions. However, in my point of view, there is significant cause for optimism. The share of labour in many industries is close to $2 / 3$. In some industries this figure is slightly lower; in others it is slightly higher. A small number of industries demonstrate rather low values of shares of labour. Throughout the history of observations in various countries, the share of consumption in the GDP has remained stable at $2 / 3$. It is not rational to take this fact to be a coincidence. Production technologies in different countries vary greatly, they continually change as time goes on. People's tastes change, new products come on the market, new materials appear, as well as sources of natural resources and energy. Economies experience rapid growth and slowdowns in economic development. In our ever-changing and inconstant world only shares of labour and capital remain stable. It is difficult to believe that this is all coincidence and not a law of production (Douglas, 1949). 


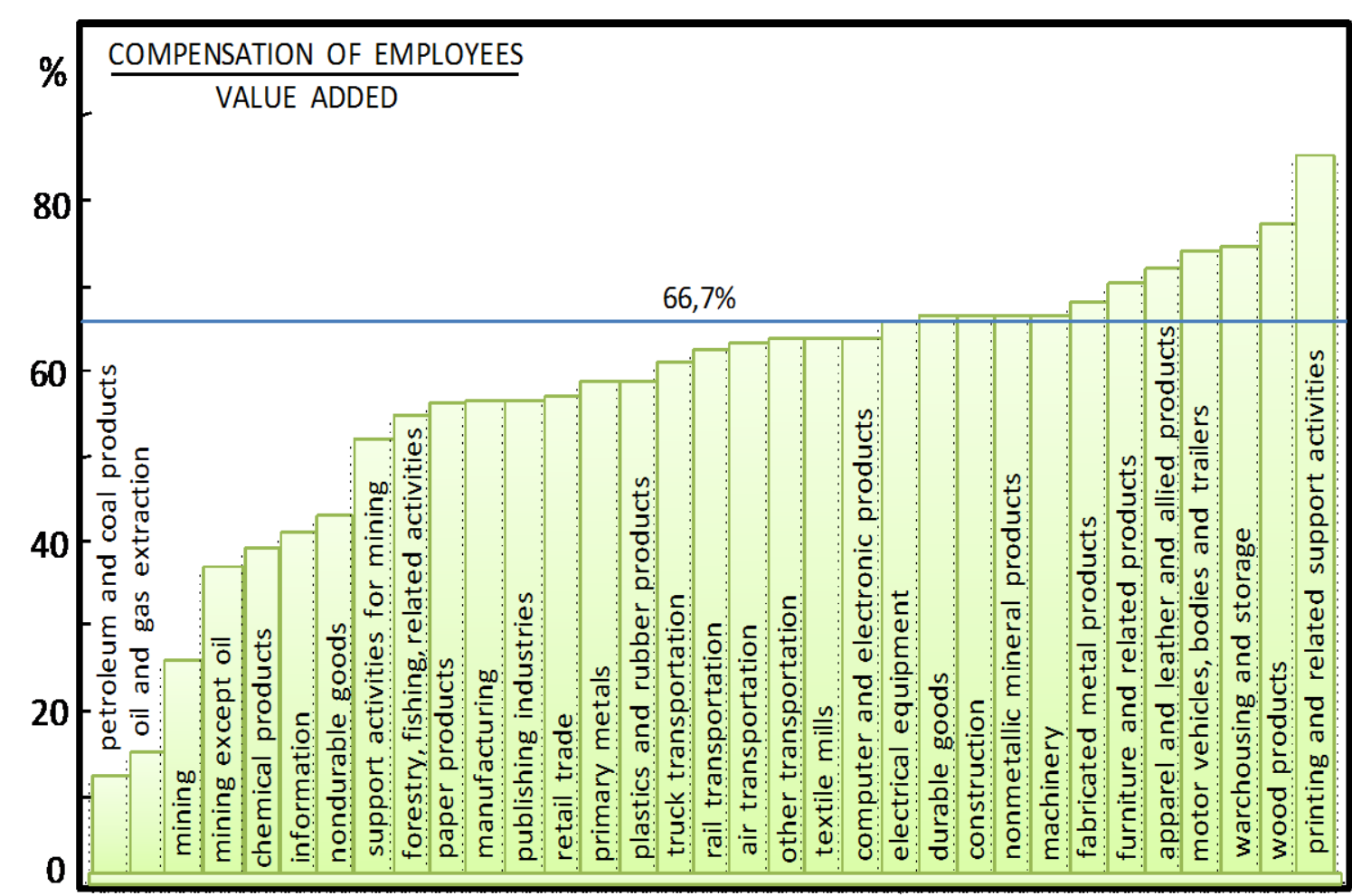

Source: Bureau of Economic Analysis. U.S. Department of Commerce (www.bea.gov).

Figure 1. Share of labour in various industries of the US economy

(average value for 2004-2011).

A few words about the dispute between the Marxists and the representatives of the Austrian school. Both sides were certainly right in this dispute. The price of a certain product is determined by both the demand and the supply. Producers set prices based on marginal production costs. Buyers purchase a certain quantity of a product and the marginal utility becomes equal to the price established by producers. The consumers value the product offered differently and therefore each of them buys a different quantity of the product. If the price of a product decreases, as a result of technological changes for example, the utility of the product becomes higher than the price. Consumers increase the quality of the product being purchased so that the marginal utility becomes equal to the price again. As mentioned above, the value of an additionally produced product is equal to the profit that will inevitably end up in the consumers' hands in the form of wages. The producers' profit becomes the consumers' profit. This means that consumers have the means to purchase additionally produced products. Equation (1) will always hold true. The producer sells the product at a price agreed with the consumer and the consumer purchases a product at a price agreed with the producer.

It is now time to discuss the main conclusions.

\section{Conclusions}

Profit is economic growth. The words profit and growth are synonyms. Any person seeking 
to earn profit increases the production of goods and services. In following their own personal interests, people help all of society to flourish. In order to make profit, any one of us has to make more end products from a certain amount of resources than other people are doing. Our end product will be greater than the price of the resources which is defined by the average marginal product for the whole market. As a result, we or an entrepreneur will receive profit. Profit is undoubtedly the reward for a more efficient use of factors of production. Therefore we or another successful entrepreneur are lawful owners of profit. It is interesting to note that we are not the only owners of entrepreneurial profit. We are only able to hold profit for a short time, its further use will inevitably turn into additional wages. Investments, savings and additional personal consumption always bring about an increase in payment for labour. The equation between wages and the value of products and services produced always holds true. This means that liberals do not always hold the trump card. The liberal's moral advantage is clear. There is no exploitation in a free market and there can be none. Exploitation only occurs when there is a certain restriction on freedom, when government officials try to actively interfere in the market mechanism for example. Without thinking they raise taxes, which reduces profit and economic growth. They try to regulate the interest rate despite the fact that the real interest rate cannot be regulated. The real interest rate is equal to the real economic growth. Many officials and union leaders consider their main job to increase the salaries of workers and employees. However their dreams are not destined to become true. Real wages cannot be increased. Of course you can take them from somebody and give them to somebody else. This is all that can be achieved with such actions. You could also print lots of money and increase inflation, but this will have no effect on the standard of living. The work of an official is not valued by the market. Officials are outside of the market. Their salary is in no way connected to the marginal product. The marginal product of an official may be higher or lower than their remuneration of labour. The latter alternative of payment is probably much more common. If the remuneration of labour of an official is greater than his or her marginal product, this means that in the country there are citizens who receive less than the amount of their marginal product. Only under these circumstances will the equation between salaries and the total cost of all goods and services produced hold true. Rather than being an exception, exploitation becomes a rule in a centralised planned economy. There is no mechanism to evaluate the marginal product in a planned economy. Wages are established centrally. The number of officials and institutions of suppression expand uncontrollably. Some people work in inhumane conditions, whilst others devise Napoleonic plans that are simply not feasible. Marx's recommendations are very much mistaken. His friend turned out to be a sworn enemy and his enemy a loyal friend.

On the whole Marx's labour theory of value is true, if you take out "abstract labour" and any mention of exploitation. The total value of all goods and services produced is equal to the value of labour. Criticism of Marx's idea has not always been justified. Marx's opponents were frightened off by the radical conclusions of the theory and did not pay much attention to its essence. They were not able to successfully attack the foundations of the labour theory of value; they simply tried to defend themselves from its unpredictable influence. Marx made a rather large contribution to economic science and is still one of the most read authors in the world. His economic interpretation of the evolution of human society is to be commended. 


\section{Macrothink}

Business and Economic Research ISSN 2162-4860 2013, Vol. 3, No. 1

However, as usually happens, the most questionable part of his achievements left the deepest mark in history and continues to motivate the minds of many.

\section{References}

Bilych G. (2012). Profit and Economic Growth. Bisiness and Economic Research, 2(2). http://dx.doi.org/10.5296/ber.v2i2.2285

Bohm-Bawerk E. V. (1948). Karl Marx and the Close of his System. Ed. by P. Sweesy. New York: Kelly.

Bohm-Bawerk E. V. (1959). Capital and Interest. The History and Critique of Interest Theories. G.D. Hunke and H.F. Sewholz, tr. Libertarian Press.

Brown M., Falk A., \& Fehr E. (2002). Contractual Incompleteness and the Nature of Market Interaction. CEPR Discussion Paper No 3272.

Chirinko R. S., Fazzari S. M. \& Meyer A. P. (1999). How Responsive is Business Capital Formation to its User Cost? Journal of Public Economics, 74(1). P. 53-80. http://dx.doi.org/10.1016/S0047-2727(99)00024-9

Cuciuba S. E. (2010). Transitional Dynamics of Output and Factor Income Shares: Lessons from East Germany. Federal Reserve Bank of Dallas. Globalization and Monetary Policy Institute. Working Paper No3. Jan.

Douglas P. H. (1949). Are There Laws of Production? American Economic Review, 38, 1-41.

Dumenil G. (1983). Beyond the Transformation Riddle: A Labour Theory of Value. Science and Society. Vol. 47. Issue 4. P. 427-450.

Escosura L. P. \& Roses J. P. (2003). Wages and Labor Income in History: A Survey. Working Papers in Economic History. Universidad Carlos III. Departamento de Historia Economica e Instituciones.

Felipe J. (2001). Aggregate Production Functions and Measurement of Infrastructure Productivity: A Reassessment. Eastern Economic Journal, 27(3).

Fisher F. M., Solow R., \& Kearl J. M. (1977). Aggregate Production Functions: Same CES Experiments. Review of Economic Studies. 44(2). 305-320. http://dx.doi.org/10.2307/2297068

Foley D. K. (2000). Recent Developments in the Labor Theory of Value. Review of Radical Political Economics, 32(1), 1-39.

Keynes J. M. (1939). Relative Movements of Real Wages and Output. Economic Journal, 49, 193. http://dx.doi.org/10.2307/2225182

Klump R., McAdam P., \& Willman A. (2011). The Normalized CES Production Function. Theory and Empirics. Working Paper Series. N 1294. February.

Loranger J. G. (2004). A Profit-Rate Invariant Solution to the Marxian Transformation 


\section{Macrothink}

Business and Economic Research

ISSN 2162-4860 2013, Vol. 3, No. 1

Problem. Capital and Class, (82), 23-58. http://dx.doi.org/10.1177/030981680408200104

Morishima M. (1973). Marx`s Economics: A Dual Theory of Value and Growth. Cambridge: Cambridge University Press.

Marx K. (1976). Capital. Volume 1. Penguin Books. London and New York.

Mises L. Von. (2008). Profit and Loss. Ludwig von Mises Institute. Alabama. U.S.A.

Reder M. W. (1959). Alternative Theories of Labor's Share. The allocation of Economic Resources. (Ed. By Abramovitz et al.). New York. P. 180-206.

Sraffa P. (1960). Production of Commodities by Means of Commodities. Cambridge. Cambridge University Press.

Steedman I. (2003). Marx After Sraffa and the Open Economy. Discussion Papers in Economics Manchester Metropolitan University. Working Paper: 2003-02. ISSN 1460-4906.

Stigler G. G. (1946). Ricardo and the 93\% Labor Theory of Value. American Economic Review, 36. June. P. 258-277.

\section{Copyright Disclaimer}

Copyright reserved by the author(s).

This article is an open-access article distributed under the terms and conditions of the Creative Commons Attribution license (http://creativecommons.org/licenses/by/3.0/). 